\title{
Solar Tracking System Untuk Mengoptimalkan Penyerapan Energi Matahari Pada Solar Cell Menggunakan Mikrokontroler Atmega 8535
}

\author{
Samaria Chrisna HS \\ Program Studi Teknik Elektronika, Jurusan Teknik Elektro \\ Politeknik Negeri Medan \\ Jl. Almamater No.1 Kampus USU Medan Telp. (061)8210371 Kodepos 20155 \\ e-mail: hetryn@gmail.com
}

\begin{abstract}
Abstrak - Penggunaan solar cell sudah semakin sering digunakan dalam pemanfaatan cahaya matahari sebagai masukan untuk menghasilkan daya listrik. Dalam prakteknya, pemasangan posisi solar cell hanya pada satu posisi tertentu sehingga penyerapan cahaya matahari tidak maksimum. Untuk peningkatan dari penyerapan cahaya matahari, maka posisi solar cell dipasang tetap berhadapan dengan arah datangnya sinar matahari ataupun solar cell harus selalu mengikuti arah pergerakan matahari sehingga diperlukan suatu tracking system pada pemasangan solar cell. Modul solar tracking system dalam penelitian ini menggunakan LDR, motor servo dan mikrokontroler ATMEGA 8535 dimana dari hasil pengujian modul menunjukkan peningkatan dalam penyerapan energi matahari jika solar cell mengikuti arah datangnya sinar matahari.
\end{abstract}

Kata kunci : Solar Cell, Tracking System, Mikrokontroler ATMega8535

\begin{abstract}
The use of solar cells is increasingly being used in the use of sunlight as input to produce electricity. In practice, the installation of the solar cell position is only in one particular position so that the absorption of sunlight is not maximum. To increase the absorption of sunlight, the position of the solar cell is fixed still facing the direction of the coming of sunlight or the solar cell must always follow the direction of the movement of the sun so that we need a tracking system in the installation of solar cells. The solar tracking system module in this study uses the LDR, servo motor and ATMEGA 8535 microcontroller where the module test results show an increase in the absorption of solar energy if the solar cell follows the direction of sunlight.
\end{abstract}

Keywords : $\quad$ Solar Cell, Tracking System, ATMega8535 Microcontroller

\section{PENDAHULUAN}

Pemanfaatan energi surya sebagai sumber energi alternatif bagi pemenuhan kebutuhan listrik di Indonesia sangatlah tepat mengingat letak geografis yang berada di daerah tropis dengan panas matahari tersedia sepanjang tahun. Keadaan alam indonesia yang relatif sulit dijangkau oleh jaringan listrik terpusat menyebabkan pilihan terhadap energi surya merupakan suatu keharusan (Septiadi dkk, 2009). Penggunaan solar cell sudah umum digunakan sekarang ini sebagai penyerap energi matahari untuk menghasilkan daya listrik yang dapat digunakan untuk mengoperasikan peralatan - peralatan elektronika. Demikian juga penggunaan mikrokontroler, sudah semakin banyak penerapannya sebagai kendali utama dalam sistem perangkat lunak yang dipasang pada perangkat yang membutuhkan kendali.

Pemanfaatan mikrokontroler pada solar tracking system ini berfungsi sebagai pengendali utama untuk mengerakkan modul solar tracking system sehingga penyerapan energi matahari pada solar cell semakin maksimum. Semakin besar energi matahari yang mengenai solar cell, maka akan semakin besar energi listrik yang dihasilkan oleh solar cell tersebut. Untuk mendapatkan energi matahari yang maksimal, maka posisi solar cell tersebut harus selalu tegak lurus terhadap arah fokus datangnya sinar matahari, dengan demikian solar cell harus selalu mengikuti arah pergerakan matahari.

Solar tracking system yang diharapkan dapat bekerja optimal untuk menyerap energi matahari, maka diperlukan suatu sistem mekanis yang dapat menggerakan posisi solar cell sehingga solar cell selalu mengikuti arah pergerakan matahari.

Sebagai pembaca arah datangnya sinar matahari diperlukan sensor peka cahaya dengan pemasangan di beberapa titik sesuai sudut arah datangnya sinar matahari. Dengan kondisi ini maka solar cell akan selalu mendapatkan sinar matahari secara optimal sehingga semakin besar energi matahari yang didapatkan solar cell maka semakin maksimal pula energi listrik yang dihasilkan.

\section{TINJAUAN PUSTAKA}

\subsection{Mikrokontroler AVR ATMega 8535}

Mikrokontroler adalah IC yang dapat diprogram berulang kali, baik ditulis atau dihapus (Agus Bejo, 2007). Biasanya digunakan untuk pengontrolan otomatis dan manual pada perangkat elektronika. 
Seiring perkembangan elektronika, mikrokontroler dibuat semakin kompak dengan bahasa pemrograman yang juga ikut berubah. Salah satunya adalah mikrokontroler AVR (Alf and Vegard's Risc processor) ATMega8535 yang menggunakan teknologi RISC (Reduce Instruction Set Computing) dimana program berjalan lebih cepat karena hanya membutuhkan satu siklus clock untuk mengeksekusi satu instruksi program. Secara umum, AVR dapat dikelompokkan menjadi 4 kelas, yaitu kelas ATtiny, keluarga AT90Sxx, keluarga ATMega, dan AT86RFxx. Pada dasarnya yang membedakan masing-masing kelas adalah memori, peripheral, dan fungsinya. Dari segi arsitektur dan instruksi yang digunakan, mereka bisa dikatakan hampir sama.

Mikrokontroler AVR ATMega8535 memiliki fitur yang cukup lengkap. Mikrokontroler AVR ATMega8535 telah dilengkapi dengan ADC internal, EEPROM internal, Timer/Counter, PWM, analog comparator, dll (M.Ary Heryanto, 2008). Sehingga dengan fasilitas yang lengkap ini memungkinkan kita belajar mikrokontroler keluarga AVR dengan lebih mudah dan efisien, serta dapat mengembangkan kreativitas penggunaan mikrokontroler ATMega8535. Untuk konfigurasi pin ATMega8535 diperlihatkan pada gambar berikut.

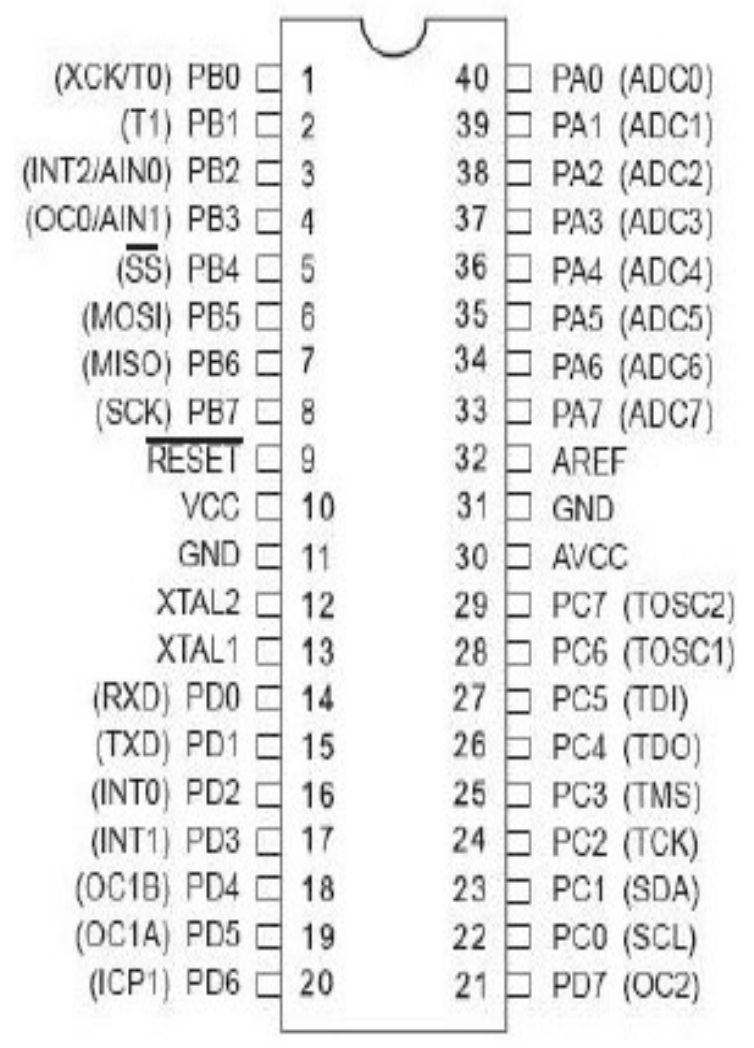

Gambar 1 Konfigurasi pin ATMega8535

Dari gambar dapat dijelaskan fungsi dari masingmasing pin ATMega 8535 sebagai berikut:
1. VCC merupakan pin yang berfungsi sebagai masukan catu daya.

2. GND merukan pin Ground.

3. Port A (PortA0...PortA7) merupakan pin input/output dua arah dan pin masukan ADC.

4. Port B (PortB0...PortB7) merupakan pin input/output dua arah.

5. Port C (PortC0...PortC7) merupakan pin input/output dua.

6. Port D (PortD0...PortD7) merupakan pin input/output dua.

7. RESET merupakan pin yang digunakan untuk mereset mikrokontroler.

8. XTAL1 dan XTAL2 merupakan pin masukan clock eksternal.

9. AVCC merupakan pin masukan tegangan untuk ADC.

10. AREFF merupakan pin masukan tegangan referensi ADC.

\subsection{Solar Cell}

Solar cell adalah suatu element aktif yang mengubah cahaya matahari menjadi energi listrik. dimana bentuk fisik dari sensor yang digunakan pada dapat dilihat pada gambar 2.2.

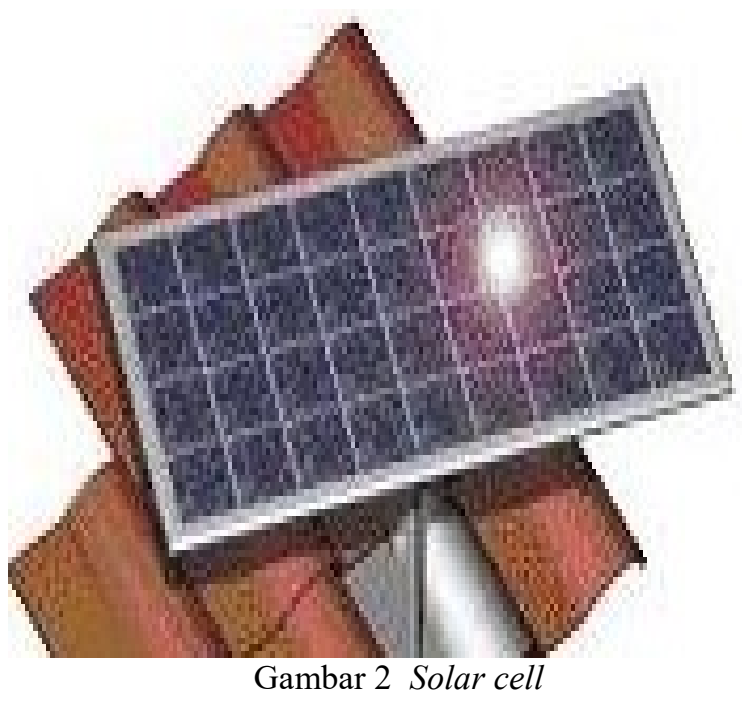

Spesifikasi keseluruhan dari solar cell yang digunakan adalah:

1. Kekuatan daya maximum : 10 Watt.

2. Kekuatan arus yang mengalir maximum: 0.59 Ampere.

3. Kekuatan tegangan yang mengalir maximum: 18.8 Volt

4. Berat secara fisik: $1.8 \mathrm{Kg}$.

5. Ukuran fisik: 450x 240x $40 \mathrm{~mm}$.

6. Tegangan maximum dalam sistem : 200V.

7. Kondisi keseluruhan : $\mathrm{AM}=1.5 \mathrm{E}=1000 \mathrm{~W} / \mathrm{m} 2$ $\mathrm{Tc}=250 \mathrm{C}$ 
Solar cell pada umumnya memiliki ketebalan 0.3 $\mathrm{mm}$, yang terbuat dari irisan bahan semikonduktor dengan kutub (+) dan kutub (-). Apabila suatu cahaya jatuh padanya maka pada kedua kutubnya timbul perbedaan tegangan yang tentunya dapat menyalakan lampu, menggerakan motor listrik yang berdaya DC. Untuk mendapatkan daya yang lebih besar bisa menghubungkan solar cell secara seri atau paralel tergantung sifat penggunaannya. Prinsip dasar pembuatan solar cell adalah memanfaatkan efek fotovoltaik yakni suatu efek yang dapat merubah langsung cahaya matahari menjadi energi listrik.

Cara kerja solar cell adalah suatu element elektroda yang terjadi dua lapisan yaitu lapisan $\mathrm{N}$ dan P. Apabila elektroda N diberi cahaya maka antara kedua elektroda tersebut akan memberikan tegangan listrik atau tegangan DC.

\subsection{Motor Servo}

Motor servo pada dasarnya adalah motor DC dengan kualifikasi khusus yang sesuai dengan aplikasi "sevosing" didalam teknik control. Secara umum dapat didefenisikan bahwa motor harus memilki kemampuan yang baik dalam mengatasi perubahan yang cepat dalam posisi dan kecepatan. Motor servo juga dikehendaki handal dalam beroperasi dalam lingkup torsi yang berubah berubah. Putaran motor tidak lagi berdasarkan tegangan suplai ke motor, namun berdasarkan tegangan input khusus yang berfungsi sebagai referensi kecepatan output.

Motor servo merupakan motor yang diatur dan dikontrol menggunakan pulsa. Motor standard ini memiliki tiga posisi yaitu posisi $0^{\circ}$, posisi $90^{\circ}$, dan posisi $180^{\circ}$. Poros motor servo biasanya dihubungkan dengan suatu mekanisme sehingga dapat membuat / mengontrol pergerakan roda depan pada sebuah mobil mainan. Pada saat poros pada posisi $0^{0}$, maka roda mobil mainan akan bergerakan kekiri, jika posisi poros pada $90^{\circ}$, maka roda depan mobil maianan akan lurus, sedangkan jika posisi $180^{\circ}$, maka roda depan mobil akan berbelok ke kanan.

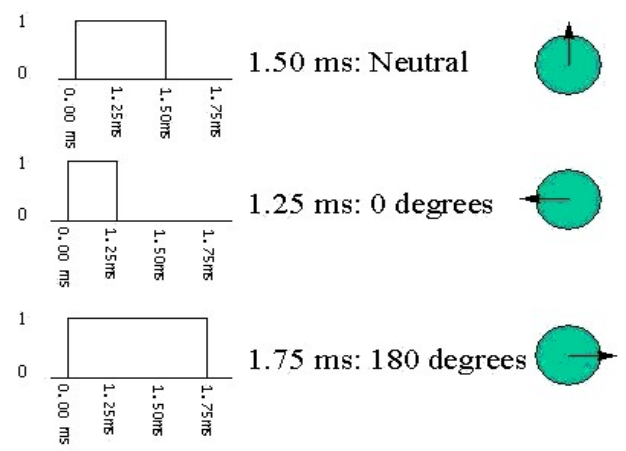

Gambar 3 Pemberian Pulsa pada Pergerakan Motor Servo
Karena ada tiga posisi utama seperti yang diperlihatkan maka dibuatlah secara khusus mengatur motor servo tersebut, dengan cara memberikan pulsa digital dengan lebar yang berbeda - beda. Jika diberikan pulsa dengan lebar $1.5 \mathrm{~ms}$ maka motor servo akan berputar $90^{\circ}$, pulsa dengan $1.75 \mathrm{~ms}$ akan membuat motor servo menuju $180^{\circ}$, sedangkan pulsa dengan lebar $1.25 \mathrm{~ms}$ akan membut motor servo bergerak menuju $0^{0}$, motor servo tersebut disebut motor servo standar yang memiliki batas, hal ini menyebabkan poros servo tidak berputar $360^{\circ}$, sedangkan motor servo kontinu jika diberi pulsa $1.25 \mathrm{~ms}$ akan berputar Clock Wise (searah jarum jam), jika diberi $1.75 \mathrm{~ms}$ maka akan berputar Counter Clock Wise (berlawanan arah jarum jam), bila diberi $1,5 \mathrm{~ms}$ motor servo akan diam tidak bergerak. Pada dasarnya motor servo kontinu akan berputar $360^{\circ}$.

Motor servo yang digunakan yaitu motor servo standar $180^{\circ}$, motor servo jenis ini hanya mampu bergerak dua arah $\mathrm{CW}$ (Clock Wise) dan CCW (Counter Clock Wise) dengan defleksi masing-masing sudut mencapai $90^{\circ}$ sehingga total defleksi sudut dari kanan - tengah - kiri adalah $180^{\circ}$. Operasional motor servo dikendalikan oleh sebuah pulsa selebar $\pm 20 \mathrm{~ms}$, dimana lebar pulsa antara $0.5 \mathrm{~ms}$ dan $2 \mathrm{~ms}$ menyatakan akhir dari range sudut maksimum. Apabila motor servo diberikan pulsa dengan besar $1.5 \mathrm{~ms}$ mencapai gerakan $90^{\circ}$, maka bila kita berikan pulsa kurang dari $1.5 \mathrm{~ms}$ maka posisi mendekati $0^{\circ}$ dan bila diberikan pulsa lebih dari $1.5 \mathrm{~ms}$ maka posisi mendekati $180^{\circ}$.

\subsection{Light Dependent Resistor (LDR)}

LDR (Light Dependent Resistant) merupakan suatu jenis resistor yang nilai resistansinya berubah-ubah karena adanya intensitas cahaya yang diserap. LDR dibentuk dari Cadium Sulfide (CDS) yang mana Cadium Sulfide dihasilkan dari serbuk keramik. Prinsip kerja LDR ini pada saat mendapatkan cahaya maka tahanannya turun, sehingga pada saat LDR mendapatkan kuat cahaya terbesar maka tegangan yang dihasilkan adalah tertinggi. Pada saat gelap atau cahaya redup, bahan dari cakram pada LDR menghasilkan elektron bebas dengan jumlah yang relatif kecil. Sehingga hanya ada sedikit elektron untuk mengangkut muatan elektrik. Artinya pada saat cahaya redup LDR menjadi pengantar arus yang kurang baik, atau bisa disebut juga LDR memiliki resistansi yang besar pada saat gelap atau cahaya redup. Pada saat cahaya terang, ada lebih banyak elektron yang lepas dari bahan semikonduktor tersebut. Sehingga akan ada lebih LDR menjadi konduktor atau bisa disebut juga LDR memilki resistansi yang kecil pada saat cahaya terang. Simbol LDR seperti ditunjukan menunjukkan grafik hubungan antara resistansi dan intensitas cahaya. 


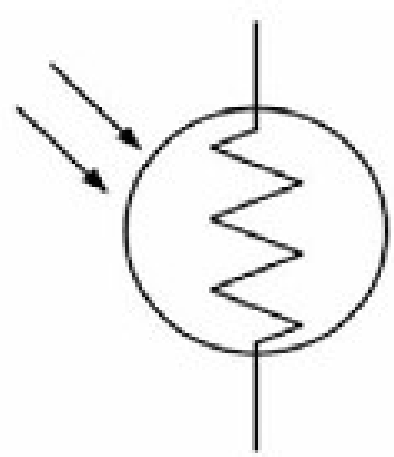

Gambar 4 Simbol LDR

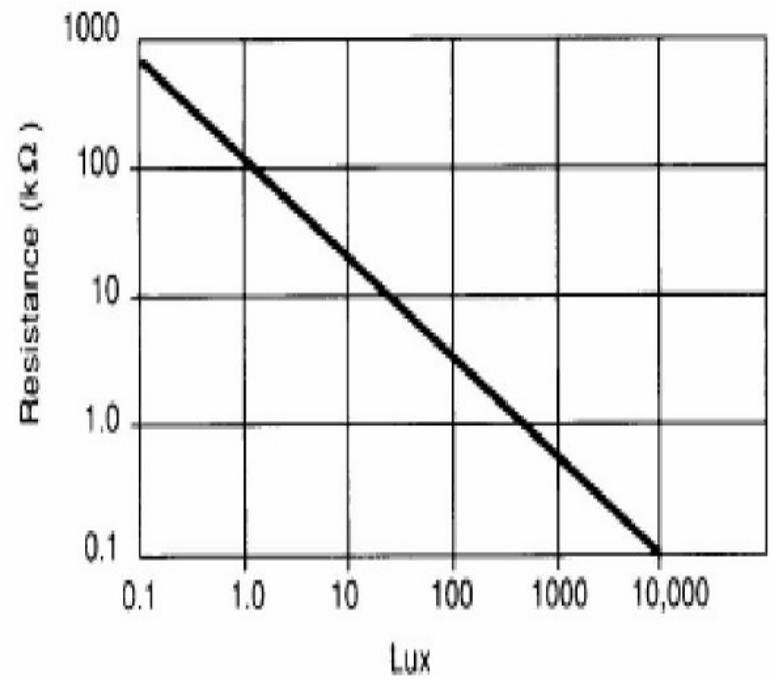

Gambar 5 Grafik hubungan antara resistansi dan intensitas cahaya

\section{RANCANGAN SISTEM}

\subsection{Proses Kerja Sistem}

Secara garis besar, alat yang dirancang terdiri dari input, proses dan output seperti diperlihatkan pada gambar .
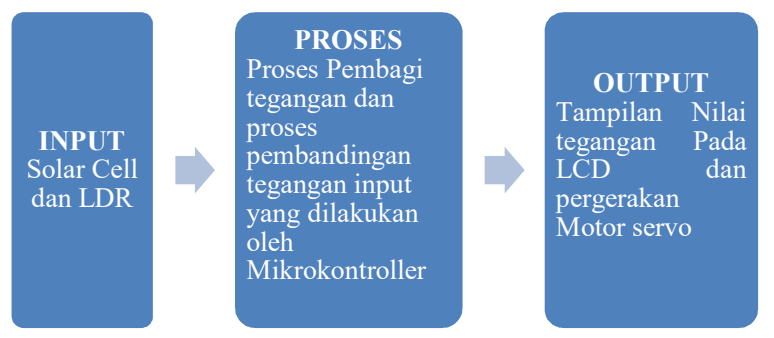

\section{Gambar 6 Diagram Proses}

Input alat berasal dari tegangan analog dari solar cell dan LDR. Solar cell menghasilkan tegangan analog, dimana tegangan tersebut bervariasi sesuai dengan kadar intensitas cahaya yang mengenai solar cell tersebut. Input alat yang lainnya berasal dari tegangan LDR. LDR berfungsi untuk menerima intensitas cahaya pada tiga titik yang berbeda, untuk kemudian dibandingkan oleh mikrokontroller titik mana yang memiliki nilai intensitas paling tinggi.

Proses yang terjadi pada alat ini ada 2 , yaitu proses pembagi tegangan yang dilakukan oleh rangkaian pembagi tegangan, dan proses pembandingan nilai input yang berasal dari LDR. Proses pembagi tegangan berfungsi untuk menurunkan tegangan. Solar Cell memiliki tegangan output sekitar 10 Volt, sedangkan mikrokontroller memiliki ADC dengan input maksimum <5Volt, karena itu dibutuhkan rangkaian pembagi tegangan agar tegangan yang masuk ke ADC mikrokontroller tidak melebihi 5 Volt.

Proses berikutnya adalah proses pembandingan tegangan LDR, fungsi proses ini adalah untuk menentukan titik mana yang memiliki nilai intensitas paling tinggi, sehingga mikrokontroller dapat mengarahkan solar cell ke titik tersebut.

Output dari rangkaian ini adalah tampilan tegangan solar cell dan pergerakan motor servo untuk menggerakkan solar cell kearah titik yang paling besar terkena sinar matahari.

Adapun diagram blok dari sistem yang dirancang adalah seperti yang diperlihatkan pada gambar.

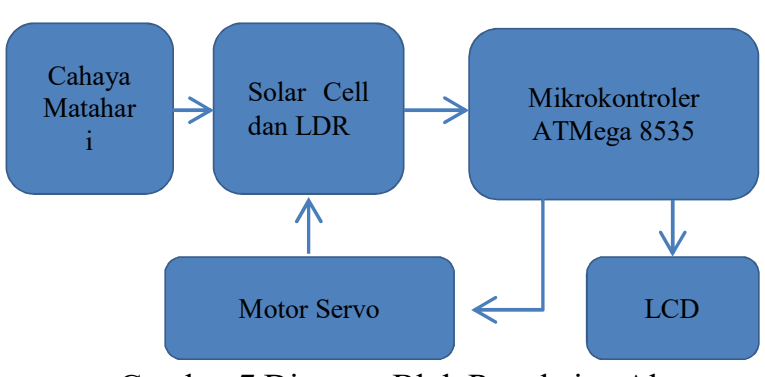

Gambar 7 Diagram Blok Rangkaian Alat

LDR sebagai sensor cahaya yang saat terkena matahari akan memberikan masukan bagi mikrokontroler sebagai data pembanding untuk penentuan posisi solar cell sehingga solar cell mendapatkan cahaya matahari secara maksimal. Cahaya matahari yang diterima oleh solar cell akan diubah menjadi listrik dan tegangan outputnya akan diukur. Selanjutnya masukan dari LDR dan solar cell akan dikirim ke mikrokontroler namun melalui proses pembagian tegangan dengan mendapatkan tegangan output dari LDR agar dapat diumpankan ke ADC dari mikrokontroler ATMega8535. Rangkaian ATMega 8535 merupakan pusat kendali dari sistem, mikrokontroller akan menerima masukan dari LDR, solar Cell dan selanjutnya nilainya akan ditampilkan pada LCD, dan ATMega8535 juga mengendalikan pergerakan servo.

\subsection{Rangkaian Mikrokontroler ATMEGA8535}

Penggunaan Mikrokontroller ATMega8535 berfungsi untuk membaca input dari sensor LDR dan solar cell, dan menampilkannya pada display LCD. 
Rangkaian ini berfungsi sebagai pusat kendali dari seluruh sistem yang ada. Komponen utama dari rangkaian ini adalah IC mikrokontroler ATMega8535. Dalam menjalankan chip IC mikrokontroler ATMega8535 memerlukan komponen elektronika pendukung lainnya. Suatu rangkaian yang paling sederhana dan minim komponen pendukungnya disebut sebagai suatu rangkaian sistem minimum. Rangkaian mikrokontroler ATMega8535 ditunjukkan pada gambar.

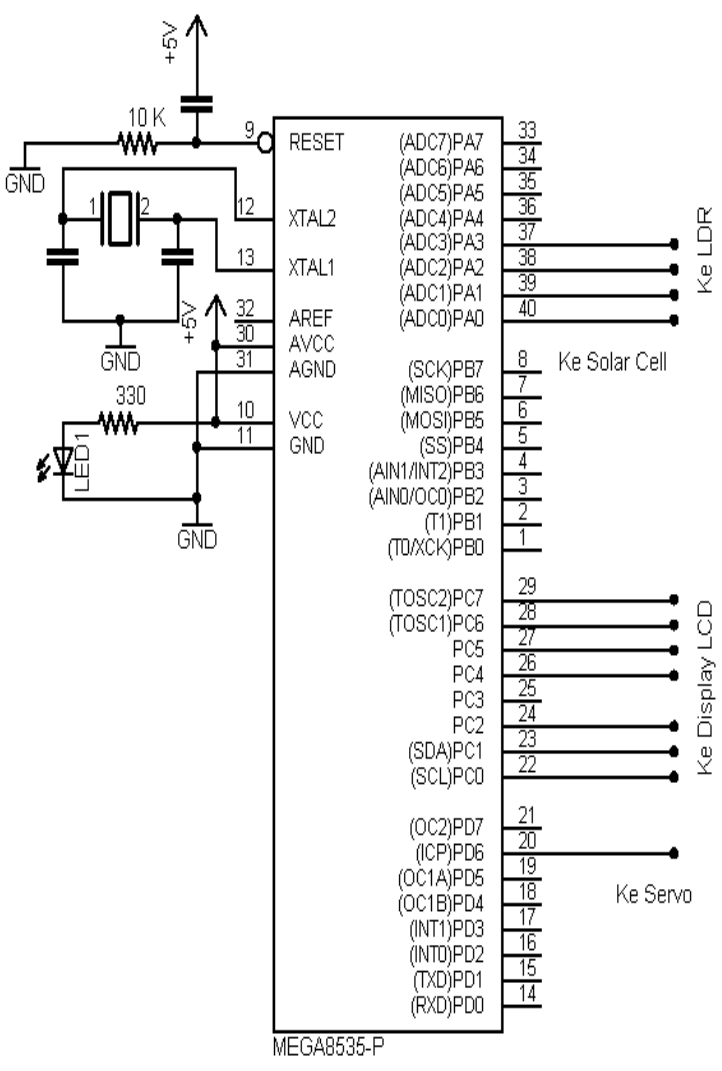

Gambar 8 Rangkaian Mikrokontroller ATMega8535

Mikrokontroler ini memiliki 32 port I/O, yaitu port A, port B, port C dan port D. Pin 33 sampai 40 adalah Port A yang merupakan port ADC, dimana port ini dapat menerima data analog. Pin 1 sampai 8 adalah port B. Pin 22 sampai 29 adalah port C. Dan Pin 14 sampai 21 adalah port D. Pin 10 dihubungkan ke sumber tegangan 5 volt. Dan pin 11 dihubungkan ke ground. Rangkaian mikrokontroler ini menggunakan komponen kristal sebagai sumber clocknya. Nilai kristal ini akan mempengaruhi kecepatan mikrokontroler dalam mengeksekusi suatu perintah tertentu. Pada pin 9 dihubungkan dengan sebuah kapasitor dan sebuah resistor yang dihubungkan ke ground. Kedua komponen ini berfungsi agar program pada mikrokontroler dijalankan beberapa saat setelah power aktip. Lamanya waktu antara aktipnya power pada IC mikrokontroler dan aktipnya program adalah sebesar perkalian antara kapasitor dan resistor tersebut. Pada perancangan ini PORTC dihubungkan dengan LCD, PORTA dihubungkan dengan LDR dan solar Cell dan PORTD.6 dihubungkan ke motor servo. Pada rancangan ini input mikrokontroller berasal dari rangkaian LDR dan solar Cell, dimana rangkaian LDR dihubungkan ke PORTA.1, PORTA.2 dan PORT A.3. sedangkan rangkaian Solar Cell dihubungkan ke PORTA.0. iniput ini berupa tegangan analog antara 0 Volt sampai 4,7 Volt. Output rangkaian mikrokontroller dihubungkan ke LCD yaitu pada PORTC. Output ini berupa data digital yaitu data parallel bernilai $0 / 1$, dimana nilai 0 merupakan tegangan 0 Volt dan nilai 1 merupakan tegangan 5 volt. Dan output lainnya dihubungkan ke motor servo yaitu pada PORTD.0. output ini berupa sinyal pulse with modulation (PWM) sinyal digital 0/1. Sinyal ini dalam bentuk PWM untuk mengendalikan servo.

\subsection{Solar Cell}

Modul solar cell Photovoltaic merubah energi cahaya menjadi arus listrik DC. Komponen utama sistem solar cell fotovoltaik adalah modul yang merupakan unit rakitan beberapa sel surya fotovoltaik. Bahan solar cell sendiri terdiri kaca pelindung dan material adhesive transparan yang melindungi bahan solar cell dari keadaan lingkungan, material antirefleksi untuk menyerap lebih banyak cahaya dan mengurangi jumlah cahaya yang dipantulkan, semikonduktor tipe $\mathrm{P}$ dan $\mathrm{N}$ (terbuat dari campuran silikon) untuk menghasilkan medan listrik, saluran awal dan saluran akhir (tebuat dari logam tipis) untuk mengirim elektron ke peralatan listrik.

Cara kerja solar cell sendiri sebenarnya identik dengan piranti semikonduktor dioda. Ketika cahaya bersentuhan dengan solar cell dan diserap oleh bahan semikonduktor, terjadi pelepasan elektron. Apabila elektron tersebut bisa menempuh perjalanan menuju bahan semikonduktor pada lapisan yang berbeda, terjadi perubahan sigma gaya-gaya pada bahan. Gaya tolakan antar bahan semikonduktor, menyebabkan aliran medan listrik. Dan menyebabkan elektron dapat disalurkan ke saluran awal dan akhir untuk digunakan pada peralatan listrik.

Dengan memberikan cahaya yang jatuh pada permukaan solar cell maka board solar cell tersebut akan menghasilkan besaran listrik pada sisi keluarannya.

Selanjutnya besarnya energi yang dihasilkan oleh solar cell ini diolah oleh mikrokontroller ATMega8535 untuk selanjutnya ditampilkan pada LCD nilai tegangan output dari solar cell. Hubungan solar cell dengan mikrokontroller ATMega8535 ditunjukkan pada 3.5: Pada perancangan ini seperti diperlihatkan gambar 3.4 digunakan nilai $\mathrm{R} 1=10.000$ ohm dan R2 $=4.700 \mathrm{ohm}$. Penempatan nilai resistor ini 
bertujuan agar nilai output dari rangkaian tidak lebih dari 5 Volt.

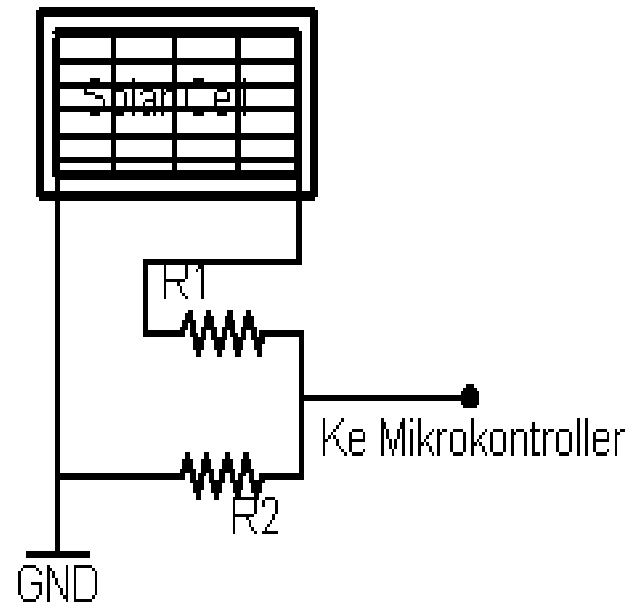

Gambar 9 Hubungan Solar Cell Ke mikrokontroller

\subsection{Motor Servo}

Sebagai pengendali pergerakan solar cell motor servo, dimana motor servo ini memiliki torsi yang besar dan presisi untuk dapat mengendalikan pergerakan solar Cell.

Motor servo adalah motor yang mampu bekerja dua arah (CW dan CCW) dimana arah dan sudut pergerakan rotornya dapat dikendalikan hanya dengan memberikan pengaturan duty cycle sinyal PWM pada bagian pin kontrolnya. Motor Servo merupakan sebuah motor DC yang memiliki rangkaian control elektronik dan internal gear untuk mengendalikan pergerakan dan sudut angularnya. Motor servo adalah motor yang berputar lambat, dimana biasanya ditunjukkan oleh rate putarannya yang lambat, namun demikian memiliki torsi yang kuat karena internal gearnya.

Sebuah motor servo memiliki 3 jalur kabel : power, ground, dan control, Sinyal control mengendalikan posisi, Operasional dari servo motor dikendalikan oleh sebuah pulsa selebar $\pm 20 \mathrm{~ms}$, dimana lebar pulsa antara $0.5 \mathrm{~ms}$ dan $2 \mathrm{~ms}$ menyatakan akhir dari range sudut maksimum, Konstruksi didalamnya meliputi internal gear, potensiometer, dan feedback control. Gambar motor servo ditunjukkan pada gambar berikut.

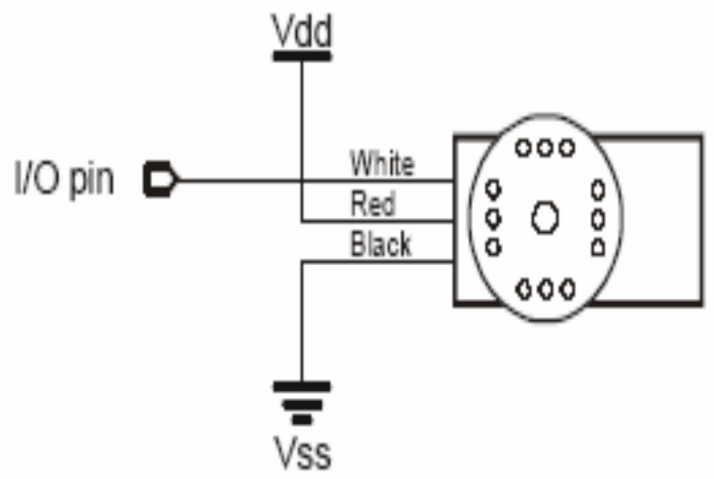

\section{Gambar 10 Pengkabelan Pada Motor Servo}

\section{PENGUJIAN SISTEM}

\subsection{Pengujian Minimum Sistem}

Pada pengujian minimum sistem ini dilakukan percobaan yang sifatnya sederhana tapi dapat menunjukkan bekerja tidaknya minimum system tersebut. Percobaan tersebut adalah menghidupkan beberapa buah LED secara bergantian. Percobaan ini dilakukan pada $\mathrm{I} / \mathrm{O}$ port (Port A). Untuk menghidupkan LED tersebut digunakan program sebagai berikut:

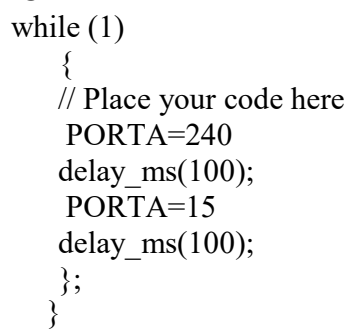

Jika program tersebut dijalankan, maka LED akan hidup dan mati bergantian seperti ditunjukkan dalam tabel 1 .

Tabel 1 Pengujian Rangkaian Mikrokontroller

\begin{tabular}{|c|c|c|c|c|c|c|c|c|}
\hline Tahap & LED & LED & LED & LED & LED & LED & LED & LED \\
& 1 & 2 & 3 & 4 & 5 & 6 & 7 & 8 \\
\hline 1 & ON & ON & ON & ON & OFF & OFF & OFF & OFF \\
\hline 2 & OFF & OFF & OFF & OFF & ON & ON & ON & ON \\
\hline
\end{tabular}

\subsection{Pengujian LCD dan Solar Cell}

Pengujian berikutnya, dengan cara menghubungkan Solar Cell ke PORDA.4 selanjutnya membaca nilainya dan ditampilkan ke LCD. Programnya sebagai berikut:

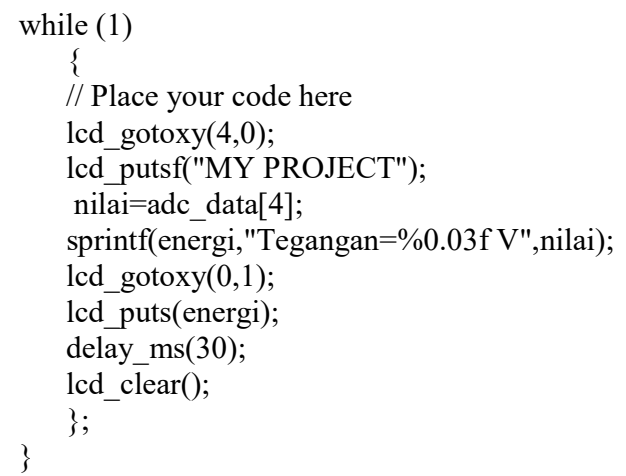

Program di atas akan membaca nilai dari PORTA.4 yang dihubungkan ke Solar Cell dengan perintah nilai=adc data[4];. Dengan perintah ini maka adc_data[4] akan dimasukkan kedalam sebuah variable bernama nilai, selanjutnya akan di ubah kedalam bentuk decimal dengan perintah sprintf(energi,"Tegangan=\%0.03f V",nilai);

kemudian akan ditampilkan ke LCD pada koordinat $\mathrm{x}=0$ dan $\mathrm{y}=1$ malalui perintah lcd gotoxy $(0,1)$; lcd_puts(energi). 
Pengujian selanjutnya dilakukan dengan menghubungkan rangkaian solar Cell dan LCD ke mikrokontroller, selanjutnya melihat tampilan pada LCD. Tampilannya ditunjukkan pada gambar 4.1.

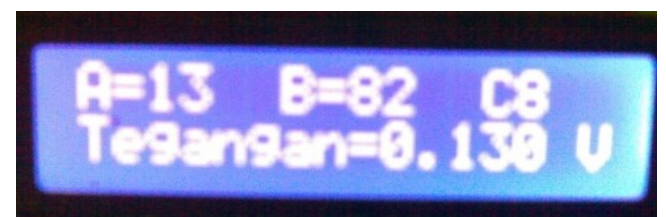

Gambar 11 Hasil Pembacaan Solar Cell dan LDR

\subsection{Pengujian Sistem Keseluruhan}

Hasil perancangan alat ditunjukkan oleh gambar 4.2. tampak bahwa alat ini terdiri dari LCD, LDR, Motor Servo, Solar Cell, rangkaian mikrokontroller ATMega8535, rangkaian pembagi tegangan dan rangkaian power supply.

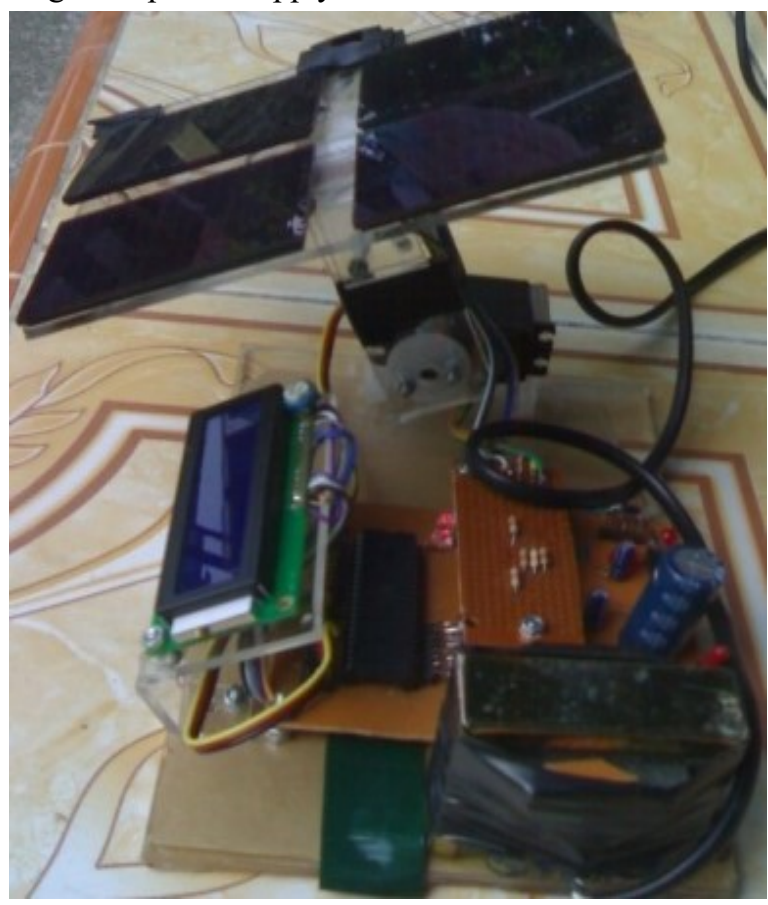

Gambar 12 Tampilan Alat Keseluruhan (dari samping)

Langkah awal pengujian ini adalah dengan menjalankan alat dan melihat proses kerjanya. Langkah pertama adalah menghubungkan alat ke sumber tegangan PLN, selanjutnya stop kontak diswitch on untuk menghidupkan alat. Langkah berikutnya adalah dilakukan pengujian dengan menempatkan alat dibawah sinar matahari. Pengujian berikutnya adalah dengan meletakkan solar cell di tempat terbuka, sehingga solar cell mandapatkan cahaya matahari secara langsung. Pengujian dimulai pada pukul 9.30 WIB sampai pukul 15.30 WIB. Dalam proses pengujian setiap setengah jam sekali nilai tegangan solar cell yang tampil pada LCD dicatat dan dilihat posisi solar cell-nya. Data hasil pengujian dapat dilihat pada tabel.

Tabel 2 Data Hasil Pengujian

\begin{tabular}{|c|c|c|c|}
\hline No & Waktu & $\begin{array}{l}\text { Tegangan } \\
\text { Solar Cell }\end{array}$ & Posisi Solar Cell \\
\hline 1 & 09.30 & $7.4 \mathrm{~V}$ & $\begin{array}{l}\text { Menghadap Arah Timur } \\
\left( \pm 25^{\circ}\right)\end{array}$ \\
\hline 2 & 10.00 & $8.7 \mathrm{~V}$ & $\begin{array}{l}\text { Menghadap Arah Timur } \\
\left( \pm 20^{\circ}\right)\end{array}$ \\
\hline 3 & 10.30 & $9.0 \mathrm{~V}$ & $\begin{array}{l}\text { Menghadap Arah Timur } \\
\left( \pm 15^{\circ}\right)\end{array}$ \\
\hline 4 & 11.00 & $9.8 \mathrm{~V}$ & $\begin{array}{l}\text { Menghadap Arah Timur } \\
\left( \pm 10^{\circ}\right)\end{array}$ \\
\hline 5 & 11.30 & $10.4 \mathrm{~V}$ & $\begin{array}{l}\text { Menghadap Arah Timur } \\
\left( \pm 5^{\circ}\right)\end{array}$ \\
\hline 6 & 12.00 & $10.7 \mathrm{~V}$ & Menghadap Atas $\left( \pm 0^{\circ}\right)$ \\
\hline 7 & 12.30 & $10.4 \mathrm{~V}$ & $\begin{array}{l}\text { Menghadap Arah Barat } \\
\left( \pm 5^{\circ}\right)\end{array}$ \\
\hline 8 & 13.00 & $10.0 \mathrm{~V}$ & $\begin{array}{l}\text { Menghadap Arah Barat } \\
\left( \pm 10^{\circ}\right)\end{array}$ \\
\hline 9 & 13.30 & $9.9 \mathrm{~V}$ & $\begin{array}{l}\text { Menghadap Arah Barat } \\
\left( \pm 15^{\circ}\right)\end{array}$ \\
\hline 10 & 14.00 & $9.5 \mathrm{~V}$ & $\begin{array}{l}\text { Menghadap Arah Barat } \\
\left( \pm 20^{\circ}\right)\end{array}$ \\
\hline 11 & 14.30 & $9.0 \mathrm{~V}$ & $\begin{array}{l}\text { Menghadap Arah Barat } \\
\left( \pm 25^{\circ}\right)\end{array}$ \\
\hline 12 & 15.00 & $8.9 \mathrm{~V}$ & $\begin{array}{l}\text { Menghadap Arah Barat } \\
\left( \pm 30^{\circ}\right)\end{array}$ \\
\hline 13 & 15.30 & $8.0 \mathrm{~V}$ & $\begin{array}{l}\text { Menghadap Arah Barat } \\
\left( \pm 35^{\circ}\right)\end{array}$ \\
\hline
\end{tabular}

\section{KESIMPULAN}

Dari hasil pelaksanaan perancangan alat hingga pengujian dan pembahasan sistem maka penulis dapat menarik kesimpulan, antara lain; Dengan menggunakan solar tracking, hasil jumlah energi yang dihasilkan oleh alat lebih baik dari pada tanpa menggunakan solar tracking. LDR merupakan sensor yang peka terhadap cahaya dapat digunakan untuk membandingkan tingkat intensitas energi yang mengenainya, yaitu dengan menggunakan beberapa LDR dan membandingkan nilai intensitas dari masing-masing LDR. Dari hasil pengujian didapatkan bahwa tingkat jumlah tegangan matahari tertinggi berada pada jam 11.30 
sampai 12.30. hal ini disebabkan karena matahari tepat berada di atas katulistiwa.

\section{DAFTAR PUSTAKA}

[1] Iswanto. 2008. "Design dan Implementasi Sistem Embedded Mikrokontroler ATMega8535 dengan Bahasa Basic". Yogyakarta: Gava Media.
[2] Iswanto. 2009. "Mikrokontroller ATmega8535 dengan Bahasa Basic". Yogyakarta: Gava Media.

[3] Setiawan, Afrie. Afrie. 2010 "Mikrokontroller ATMEGA8535 \& ATMEGA16 Menggunakan BASCOM AVR". Yogyakarta: Penerbit Andi.

[4] Wardhana, Lingga. 2006. "Belajar Sendiri Mikrokontroller AVR seri Atmega8535 Simulasi, Hardware, dan Aplikasi”. Yogyakarta: Penerbit Andi. 